\title{
Tobacco Dependence, the Most Important Cardiovascular Risk Factor: Treatment in the Czech Republic
}

\author{
E. KRÁLÍKOVÁ ${ }^{1,2}$, A. KMEŤOVÁ ${ }^{1,2}$, L. ŠTĚPÁNKOVÁ ${ }^{1}$, K. ZVOLSKÁ ${ }^{1}$, V. FELBROVÁ ${ }^{1}$, \\ S. KULOVANÁ ${ }^{1}$, Z. BORTLÍČEK ${ }^{3}$, M. BLAHA ${ }^{3}$, K. FRASER ${ }^{2}$
}

${ }^{1}$ Center for Tobacco-Dependent of the Third Medical Department - Department of Endocrinology and Metabolism, First Faculty of Medicine, Charles University in Prague and General University Hospital in Prague, Czech Republic, ${ }^{2}$ Institute of Hygiene and Epidemiology, First Faculty of Medicine, Charles University and General University Hospital in Prague, Czech Republic, ${ }^{3}$ Institute of Biostatistics and Analyses, Faculty of Medicine, Masaryk University, Brno, Czech Republic

Received July 7, 2014

Accepted July 22, 2014

\section{Summary}

Smoking is the most important cardiovascular (CV) risk factor. Stopping smoking halves the CV risk. Every clinician should provide a brief intervention with smokers. Intensive treatment should be available to those who need it. There are 37 Centers for Tobacco Dependence in the Czech Republic, which offer treatment including a psychobehavioral intervention and pharmacotherapy (varenicline, nicotine, bupropion). Czech physicians, pharmacists and nurses are regularly educated about smoking cessation. We describe the results of intensive treatment offered by our centers. Treatment includes screening $(1 \mathrm{~h})$, an intervention $(2 \mathrm{~h})$, and follow-up visits during the next 12 months. Among 3532 patients, $34.3 \%$ had CO-validated abstinence at 12-months (including 489 patients who attended the screening visit + only the 12-month follow up visit). Among patients who underwent the intervention, the abstinence rate was $38.2 \%$. The majority of patients who underwent the intervention ( $\mathrm{N}=2470)$ used some form of pharmacotherapy. After one year, the abstinence rate was $43.4 \%$, compared to $15.9 \% \quad(\mathrm{~N}=573)$ without pharmacotherapy. Only $28 \%$ of patients came on the recommendation of a physician. Despite the decrease in CV risk following smoking cessation and the effectiveness of treatment, centers are underutilized.

\section{Key words}

Tobacco dependence • Smoking cessation • Cardiovascular risk

\section{Corresponding author}

E. Králíková, Institute of Hygiene and Epidemiology, Charles University and General University Hospital, Studničkova 7, 12800 Prague 2, Czech Republic. E-mail: eva.kralikova@lf1.cuni.cz

\section{Introduction}

The pathophysiological effects of smoking are broad due to more than 4000 chemicals, including polycyclic aromatic hydrocarbons and oxidizing gases, most of which have cardiotoxic effects (Haustein 2002, Ambrose and Barua 2004). Nicotine is a sympathomimetic agent with potential cardiovascular (increase in heart rate, blood pressure and cardiac output) and metabolic effects (increased lipolysis) (Benowitz 1998, Ambrose and Barua 2004). It appears that pure nicotine itself has no significant influence on the development of CVD. Nicotine is highly addictive and causes addiction to tobacco, which results in inhalation of tobacco smoke with noxious agents (Asplund 2003). The risk of an acute $\mathrm{CV}$ event is higher among smokers due to increased coagulation which leads to thrombosis (platelet activation and aggregation, activation of coagulation, increased fibrinogen level, increased levels of tissue factor, leukocyte count, and D-dimer, and plasma viscosity) (Kannel et al. 1987, Wilhelmsen 1988, Fuster et al. 1992, Ernst 1994, Sambola et al. 2003). Even a small dose, including passive smoking, increases platelet aggregation. These findings may at least partly 
explain the higher risk of coronary thrombosis in smokers (Lee et al. 1995, Puranik and Celermajer 2003). Active and passive smoking are associated with endothelial dysfunction in a dose-dependent manner (Kato et al. 2006). There is reduced release and availability of NO and the formation of a chronic inflammatory condition (leukocytosis, elevated CRP). Smoking and hypertension have the same effect on the progression of early atherosclerosis (Csányi et al. 2001). Impaired relaxation of arteries observed in an animal model, suggests a possible degradation of NO by anionic superoxide of cigarette smoke (Török et al. 2000). In vitro studies have demonstrated the association between smoking with altered endothelial-derived fibrinolytic and antithrombotic factors: t-PA/PAI-I reduction, lower 1-TFPI (tissue factor pathway inhibitor), and reduced production of NO (Barua et al. 2002). Nicotine stimulates the production of endothelium-derived chemoattractants that enhance the migration of smooth muscle cells of blood vessels (Di Luozzo et al. 2005). Endogenous NO production may be a protective mechanism against endothelial damage induced by smoking (Raveendran et al. 2005). Nicotine increases the level of VEGF mRNA, as well as proteins in the endothelium and may increase the release of TNF-alpha and IL-1beta from macrophages (Conklin et al. 2002, Wang et al. 2004). Inhibition of endothelial cell migration in the presence of a condensate of cigarette smoke leads to a higher probability of developing complications due to incomplete reendothelialization (Snajdar et al. 2001). Smoking also has broad endocrine effects (Hruskovicova et al. 2013).

Due to CV risk all smokers, but especially those with increased $\mathrm{CV}$ risk, should be strongly advised not to smoke (diagnosis F17), and to avoid any exposure to tobacco including passive smoking (diagnosis E58.7), according to the International Classification of Diseases, $10^{\text {th }}$ version (WHO 2008).

Every clinician (physician, nurse, pharmacist) should provide a brief intervention with smokers and intensive treatment should be available to those who need it (Fiore et al. 2008). Treatment that includes a psychobehavioral intervention and pharmacotherapy (varenicline, nicotine, bupropion), is offered at Centers for Tobacco-Dependence. There are currently 37 hospital-based centers across the Czech Republic. Education of Czech physicians, pharmacists and nurses in smoking cessation regularly occurs under the Society for Treatment of Tobacco Dependence (info at www.slzt.cz).

\section{Methods}

To demonstrate the efficacy of intensive treatment, we present a cohort of patients who visited the Center for Tobacco Dependence in the Czech Republic. Smokers were self referred or referred by a physician to the center for treatment. We compared one year abstinence rates in the following groups of patients: those who only came to the center for the initial screening visit + the 12-month follow-up visit, and those who also underwent the intervention (screening, intervention and attended at least one 12-month follow-up visit). Within the group that underwent the intervention, we also compared patients who used pharmacotherapy (varenicline, nicotine, and/or bupropion) versus those who did not.

The treatment in our center starts with an initial 1-h screening visit. Each patient's level of nicotine dependence is assessed using a series of measures, including the Fagerström Test of Cigarette Dependence (FTCD) (Fagerström et al. 2012), CO in expired air, the number of cigarettes smoked in the past $12 \mathrm{~h}$, Beck Depression Scale II (BDI-II) (Beck et al. 1996), and the Minnesota Withdrawal Scale (Hughes 2007). Within one week of the initial screening visit, patients undergo a 2-h intervention with a physician. There is a mean of 4 follow-up visits during the next 12 months. The first follow-up visit usually occurs within 2 weeks of the intervention, and monthly thereafter.

The intervention with a physician is performed individually or in small groups with 4-5 individuals. Following the intervention, based on our recommendation, the patient is offered either varenicline, nicotine replacement therapy or bupropion and/or a combination. We set a quit date. Follow-up visits take about $30 \mathrm{~min}$ and include checking the patient's weight, blood pressure, and heart rate. We measure CO in expired air and discuss withdrawal symptoms, as well as we check the treatment.

The visit schedule and intervention structure are described in Table 1.

This analysis was approved by the Ethics Committee of the General University Hospital in Prague, registration FWA 00003027 - according to the Office for Human Research Protections, U.S. Department of Health and Human Services, under No. IRB 00002705. The General University Hospital is registered under No. IORG 0002175. 
Standard descriptive statistics were used to characterize the sample data set. Statistical significance of differences in 12-month abstinence rate by gender and the type of pharmacotherapy used were assessed by Fisherexact test. Statistical significance of differences in baseline characteristics between groups of patients who had undergone the intervention and those who did not was assessed by Mann-Whitney test or Pearson Chí-square test. A significance level of alpha $=0.05$ was used.

Table 1. Visit schedule for patients of the Center for Tobacco-Dependence.

\begin{tabular}{|c|c|}
\hline Screening visit & $\begin{array}{l}\text { vital signs, weight, height, heart rate, blood pressure, personal history and social background, } \\
\text { CO in expired air, withdrawal symptoms, and other tests }\end{array}$ \\
\hline $\begin{array}{l}\text { Intervention visit } \\
\text { (usually within one } \\
\text { week of the initial } \\
\text { screening visit) }\end{array}$ & 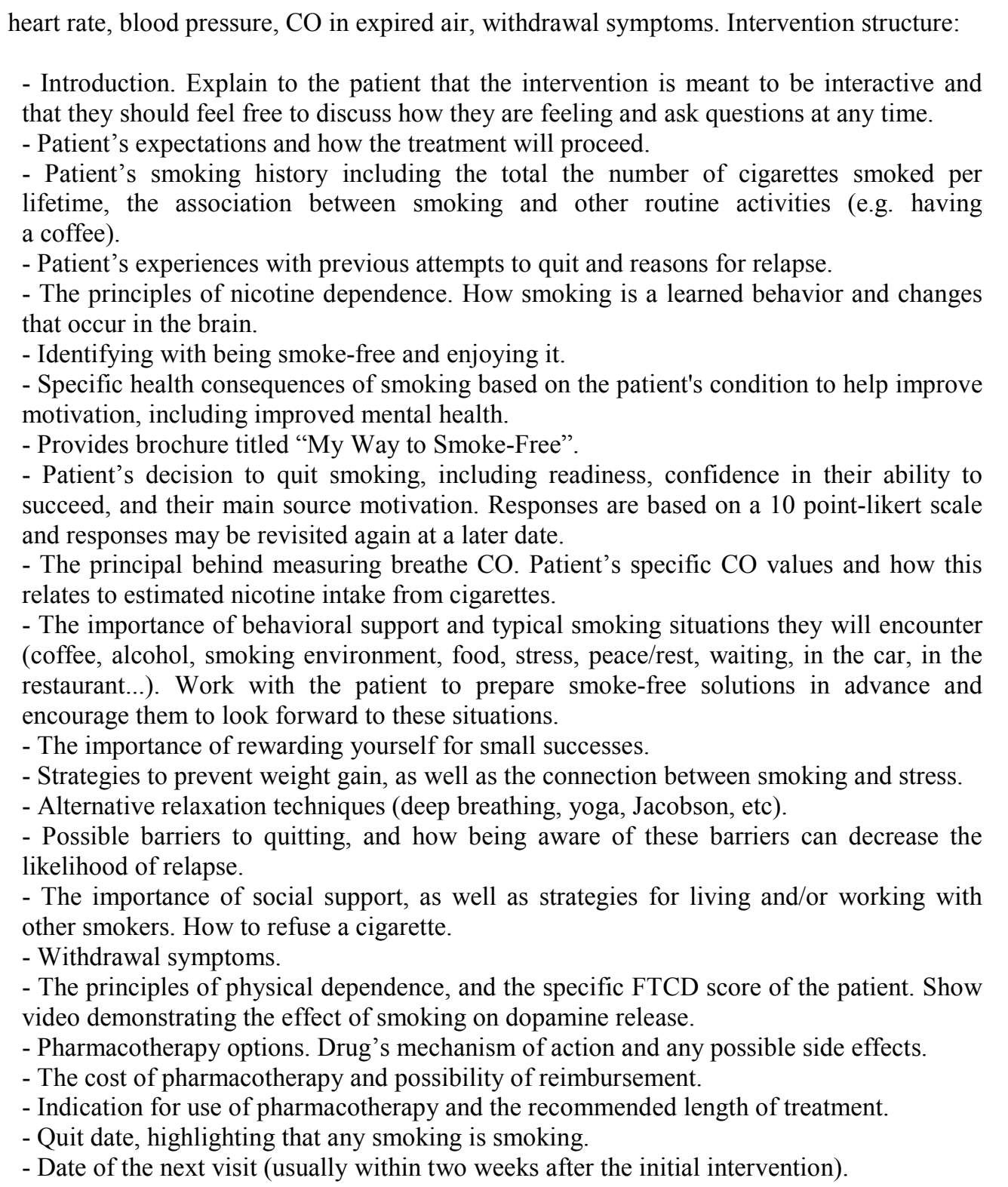 \\
\hline $\begin{array}{l}\text { Follow-up visits } \\
\text { (based on the } \\
\text { patient needs, but } \\
\text { usually within } \\
2 \text { weeks of the quit } \\
\text { date, then about } \\
3 \times \text { monthly, then at } \\
6 \text { and } 12 \text { months } \\
\text { after the quit date) }\end{array}$ & heart rate, blood pressure, $\mathrm{CO}$ in expired air, withdrawal symptoms collected at each visit \\
\hline
\end{tabular}


Table 2. A. Selected characteristics of patients of the Center for Tobacco Dependence.

\begin{tabular}{|c|c|c|c|}
\hline Characteristics & $\begin{array}{l}\text { Complete record } \\
(\mathrm{N}=3043)\end{array}$ & $\begin{array}{l}\text { Incomplete record } \\
(\mathrm{N}=489)\end{array}$ & p-value ${ }^{1}$ \\
\hline \multicolumn{4}{|l|}{ Gender } \\
\hline Male & $1526(50.1 \%)$ & $255(52.1 \%)$ & \multirow{2}{*}{0.412} \\
\hline Female & $1517(49.9 \%)$ & $234(47.9 \%)$ & \\
\hline \multicolumn{4}{|l|}{ Age at first visit } \\
\hline$\leq 29$ & $475(15.6 \%)$ & $92(18.8 \%)$ & \multirow{5}{*}{0.057} \\
\hline $30-39$ & $841(27.6 \%)$ & $113(23.1 \%)$ & \\
\hline $40-49$ & $550(18.1 \%)$ & $80(16.4 \%)$ & \\
\hline $50-59$ & $581(19.1 \%)$ & $110(22.5 \%)$ & \\
\hline$\geq 60$ & $596(19.6 \%)$ & $93(19.0 \%)$ & \\
\hline \multicolumn{4}{|l|}{ Education } \\
\hline Basic & $288(9.5 \%)$ & $59(12.1 \%)$ & \multirow{3}{*}{0.002} \\
\hline Secondary & $1905(62.6 \%)$ & $328(67.1 \%)$ & \\
\hline University & $850(27.9 \%)$ & $102(20.9 \%)$ & \\
\hline \multicolumn{4}{|l|}{ Daily smoked cigarettes } \\
\hline Up to 10 & $253(8.4 \%)$ & $62(13.0 \%)$ & \multirow{5}{*}{0.018} \\
\hline $11-20$ & $1578(52.1 \%)$ & $233(48.7 \%)$ & \\
\hline $21-30$ & $750(24.8 \%)$ & $110(23.0 \%)$ & \\
\hline $31-40$ & $332(11.0 \%)$ & $51(10.7 \%)$ & \\
\hline$>40$ & $116(3.8 \%)$ & $22(4.6 \%)$ & \\
\hline \multicolumn{4}{|l|}{ FTCD } \\
\hline $0-1$ points & $144(4.8 \%)$ & $40(8.6 \%)$ & \multirow{4}{*}{0.008} \\
\hline 2-4 points & $823(27.4 \%)$ & $118(25.3 \%)$ & \\
\hline 5-7 points & $1345(44.7 \%)$ & $200(42.8 \%)$ & \\
\hline $8-10$ points & $697(22.9 \%)$ & $109(23.3 \%)$ & \\
\hline$B M I\left(\mathrm{~kg} / \mathrm{m}^{2}\right)$ & $25.4(19.5 ; 34.5)$ & $25.5(18.9 ; 35.8)$ & 0.976 \\
\hline$\%$ body fat & $28.0(14.3 ; 42.4)$ & $28.2(13.4 ; 43.2)$ & 0.421 \\
\hline Waist-to-Hip Ratio (\%) & $87.6(71.7 ; 104.6)$ & $87.2(71.3 ; 105.6)$ & 0.730 \\
\hline CO (ppm) & $17.0(1.0 ; 38.0)$ & $15.0(0.0 ; 39.0)$ & 0.004 \\
\hline COHb (\%) & $3.0(0.3 ; 6.9)$ & $2.8(0.1 ; 6.9)$ & 0.020 \\
\hline
\end{tabular}

Patients with a complete record, who passed the intervention = at least screening, intervention and 12-month follow-up visit ( $N=3043$ ). Patients with incomplete record (screening and 12-month follow up, in case of loss to follow-up, patients were considered smokers at 12 months) ( $\mathrm{N}=489) .{ }^{1}$ Differences tested according to the Mann-Whitney U test or Pearson Chí-square test; FTCD - Fagerström Test of Cigarette Dependence; BMI - body mass index; $\mathrm{CO}$ - carbon monoxide; $\mathrm{COHb}$ - carbonylhemoglobin.

Table 2. B. Cardiovascular characteristics of patients who stopped smoking (non-smokers) and patients who continued to smoke (smokers).

\begin{tabular}{|c|c|c|c|c|c|}
\hline \multirow[b]{2}{*}{ Characteristics } & \multirow[b]{2}{*}{ Visit } & \multicolumn{2}{|c|}{ Non-smokers $(\mathrm{N}=1162)$} & \multicolumn{2}{|c|}{ Smokers $(\mathrm{N}=1881)^{1}$} \\
\hline & & $\mathbf{N}$ & $\begin{array}{l}\text { Median } \\
\text { (Min-max) }\end{array}$ & $\mathbf{N}$ & $\begin{array}{l}\text { Median } \\
\text { (Min-max) }\end{array}$ \\
\hline \multirow[t]{2}{*}{ Weight } & Baseline & 1158 & $77.0(45.0-135.3)$ & 1857 & $75.8(41.6-187.0)$ \\
\hline & 12 months follow-up & 1094 & $82.9(45.0-147.0)$ & 100 & $83.4(50.0-133.0)$ \\
\hline \multirow[t]{2}{*}{ Pulse } & Baseline & 1145 & $72(41-119)$ & 1835 & $72(45-116)$ \\
\hline & 12 month follow-up & 879 & $72(42-154)$ & 84 & $72(56-107)$ \\
\hline \multirow[t]{2}{*}{ Systolic pressure } & Baseline & 1150 & $125(85-190)$ & 1850 & $123(73-220)$ \\
\hline & 12 month follow-up & 885 & $125(85-210)$ & 85 & $126(90-180)$ \\
\hline \multirow[t]{2}{*}{ Diastolic pressure } & Baseline & 1150 & $80(50-125)$ & 1850 & $80(45-131)$ \\
\hline & 12 month follow-up & 884 & $80(50-111)$ & 85 & $80(54-105)$ \\
\hline
\end{tabular}

\footnotetext{
${ }^{1}$ Missing data in the group of smokers are due to a loss to follow-up. In such a case the patient was considered to be a smoker.
} 


\section{Results}

Our analysis included 3532 patients who had completed the 12 month follow-up between 2005 and 2013 (intention-to-treat analysis). The abstinence rate was $34.3 \%$ in all patients including those who had attended only the initial screening and the 12-month follow up visit, compared to $38.2 \%$ among those who had also undergone the intervention (initial screening visit, intervention and at least the 12-month follow-up visit). For more detail see Figures 1 and 2, and Table 2A. In Table 2B selected CV risk factors are compared. 12-month visit

\section{$\mathbf{N}=\mathbf{3 5 3 2}$}

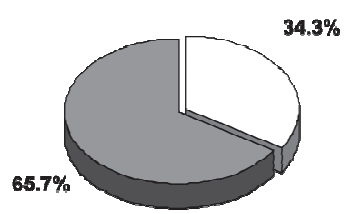

Smaker (N=2321)

Smake-free $(\mathrm{N}=1211)$

\section{2-month visit}

\section{$\mathbf{N}=\mathbf{3 0 4 3}$}

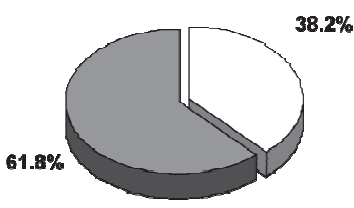

Smoker ( $N=1162)$

Smoke-free $(\mathrm{N}=1881)$ 12-month visit - according

to gender
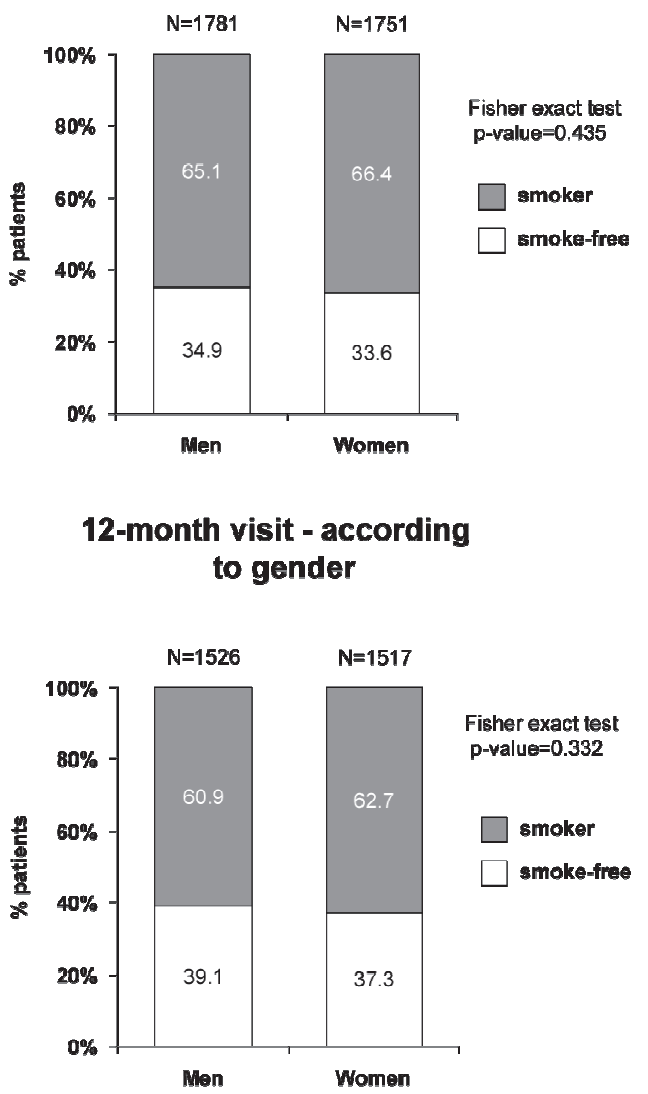

Fig. 1. 12-month abstinence rate among patients of the Center for TobaccoDependence in the Czech Republic between 2005 and 2013.

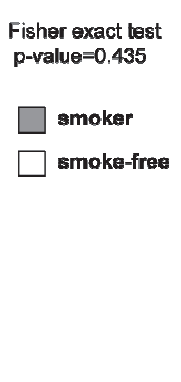

Fig. 2. 12-month abstinence rate among patients of the Center for TobaccoDependence who underwent an intensive intervention.

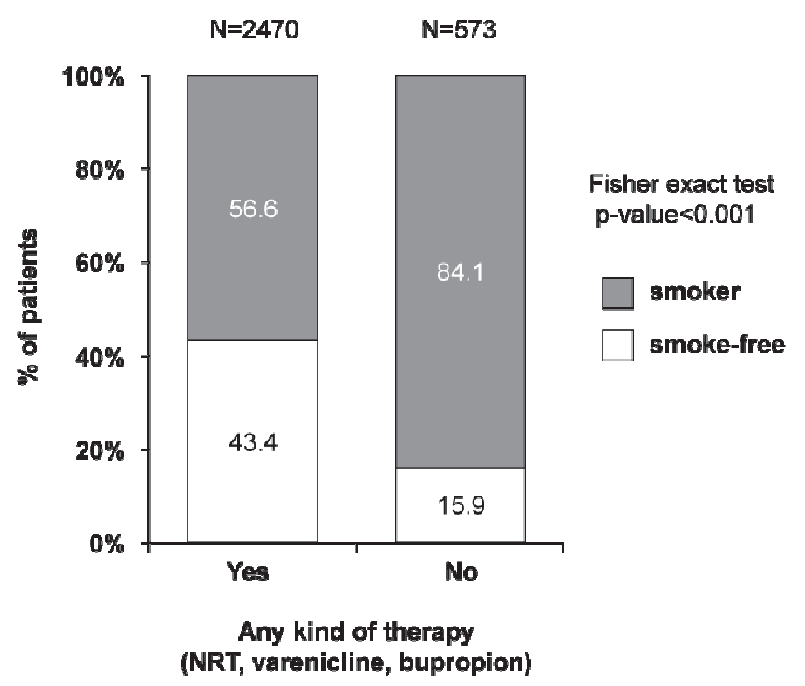

Fig. 3. 12-month abstinence rate among patients of the Center for Tobacco-Dependence who underwent an intervention according to pharmacotherapy use.
Pharmacotherapy (any kind) significantly increased the abstinence rate. The majority, $81 \%$ of patients used some form of pharmacotherapy. Among patients who had used some form of pharmacotherapy the abstinence rate was $43.4 \%$, compared to $15.9 \%$ among patients who tried to stop smoking without pharmacotherapy (Fig. 3).

Although health was the most frequent reason to stop smoking - in $68 \%$, only $28 \%$ of patients said their physician had recommended they visit our center. Most patients learned about our center by way of media, including Internet - 49\%, followed by the recommendation of other patient's - $18 \%$. The rest learned about our center from other sources (5\%).

For a more detailed description of our patients and results, including abstinence rates according to 
pharmacotherapy used, psychiatric comorbidity or $\mathrm{CV}$ risk factors see our other publications (Zvolska et al. 2012, Kralikova et al. 2013, Stepankova et al. 2013, Kmetova et al. 2014).

\section{Discussion}

Stopping smoking without any help has a low long-time success rate, about $5 \%$ (Fiore et al. 2008). Intensive treatment may increase the number of former smokers substantially. Brief smoking cessation interventions are still not a usual part of clinical practice. Eighty percent of Czech physicians report asking about tobacco use and advising patients to stop smoking, but the next steps of the brief intervention are rarely followed. It is necessary to offer help in quitting (recommend treatment or refer the patient to a Center for Tobacco-Dependence), and to plan follow-up visits (Kralikova et al. 2011). For a center located in a large hospital we would expect more than $28 \%$ of patients would be referred based on a physician's recommendation. The majority of smokers learn about intensive treatment possibility from sources other than their physician, which may suggest that brief smoking cessation intervention is not regularly used in clinical practice.

Also the diagnosis Z58.7 (passive smoking) may be a teachable moment, if used. Currently, this diagnosis is not used at all in the Czech Republic. Only $1.5 \%$ of hospitalized patients was diagnosed F17 (tobacco dependence) in 2011 (Zvolsky et al. 2012) - despite a $30 \%$ smoking prevalence in the population with about $80 \%$ of smokers being dependent (Sovinova and Csémy 2013). A similar situation was described in psychiatric care in the USA with an $88 \%$ prevalence of tobacco use among psychiatric patients, while only $2 \%$ were diagnosed. Among psychiatric patients who smoke, even more than $80 \%$ were dependent (Peterson et al. 2003).

Our results are comparable with international results. For patients receiving outpatient treatment at the Nicotine Dependence Center (NDC) of the Mayo Clinic in Minnesota, USA, the 6-month smoking abstinence rate has been reported ranging from $22 \%$ to $25 \%$. The 1 -year smoking abstinence rate for patients who enter the residential treatment program at NDC is reported to be $52 \%$. But, one limitation is that abstinence is verified there mainly by telephone only (Hurt et al. 2009).

Choice of medication depends on the intensity of addiction, but also on the patient's previous experiences, preferences, financial options, etc. Interestingly there is a fear of adverse effects with smoking cessation pharmacotherapy (either nicotine, varenicline or bupropion) among patients as well as physicians, though no adverse cardiovascular (Mills et al. 2013) or neuropsychiatric effects (Thomas et al. 2013) have been proven.

Smoking cessation intervention is a missed opportunity in cardiology despite many pathophysiological CV links that could be used to enhance patients' motivation to stop smoking. The possibility of intensive treatment of tobacco dependence could be used more broadly especially in $\mathrm{CV}$ patients or patient with elevated $\mathrm{CV}$ risk.

\section{Conflict of Interest}

EK, AK, LŠ, KZ, VF, SK received payment for clinical studies and educational activities from pharmaceutical companies producing smoking cessation medication.

\section{Acknowledgements}

Grant support: Czech Ministry of Health, IGA NT121705/2011 and PRVOUK P25/LF1/2.

\section{References}

AMBROSE JA, BARUA RS: The pathophysiology of cigarette smoking and cardiovascular disease: an update. $J A m$ Coll Cardiol 43: 1731-1737, 2004.

ASPLUND K: Smokeless tobacco and cardiovascular disease. Prog Cardiovasc Dis 45: 383-394, 2003.

BARUA RS, AMBROSE JA, SAHA DC, EALES-REYNOLDS L: Smoking is associated with altered endothelialderived fibrinolytic and antithrombotic factors - an in vitro demonstration. Circulation 106: 905-908, 2002.

BECK AT, STEER RA, BROWN GK: Manual for the Beck Depression Inventory-II. San Antonio, TX: Psychological Corporation, 1996.

BENOWITZ NL: Nicotine Safety and Toxicity. Oxford University Press, New York, 1998.

CONCLIN BS, ZHAO W, ZHONG DS, CHEN C: Nicotine and cotinine up-regulate vascular endothelial growth factor expression in endothelial cells. Am J Pathol 160: 413-418, 2002. 
CSÁNYI A, EGERVÁRI A, NAGY Z: Influence of hypertension and smoking as the single vascular risk factors on the intima-media thickness. Eur J Epidemiol 17: 855-861, 2001.

Di LUOZZO G, PRADHAN S, DHADWAL AK, CHEN A, UENO H, SUMPIO BE: Nicotine induces mitogenactivated protein kinase dependent vascular smooth muscle cell migration. Atherosclerosis 178: 271-277, 2005.

ERNST E: Fibrinogen: its emerging role as a cardiovascular risk factor. Angiology 45: 87-93, 1994.

FAGERSTRÖM K: Determinants of tobacco use and renaming the FTND to the Fagerström Test for Cigarette Dependence. Nicotine Tob Res 14: 75-78, 2012.

FIORE MC, JAÉN CR, BAKER TB, BAILEY WC, BENOWITZ NL, CURRY SJ, DORFMAN SF, FROELICHER ES, GOLDSTEIN MG, HEALTON CG, HENDERSON PN, HEYMAN RB, KOH HK, KOTTKE TE, LANDO HA, MECKLENBURG RE, MERMELSTEIN RJ, MULLEN PD, ORLEANS CT, ROBINSON L, ET AL.: Treating tobacco use and dependence. Clinical Practice Guideline. Rockwille, MD, U.S. Department of Health and Human Services. Public Health Service, 2008 update http://www.ncbi.nlm.nih.gov/books/NBK63954/ (assessed June 14, 2014).

FUSTER V, BADIMON L, BADIMON JJ, CHESEBRO JH: The pathogenesis of coronary artery disease and the acute coronary syndromes. $N$ Engl J Med 326: 310-318, 1992.

HAUSTEIN K: Tobacco or Health: Physiological and Social Damages Caused by Tobacco Smoking. Springer, Berlin, Germany, 2003.

HRUSKOVICOVA H, DUSKOVA M, SIMUNKOVA K, HILL M, POSPISILOVA H, RACZ B, KRALIKOVA E, VONDRA K, STARKA L: Effects of smoking cessation on hormonal levels in men. Physiol Res 62: 67-73, 2013.

HUGHES JR: The effects of abstinence from tobacco: valid symptoms and time course. Nicotine Tob Res 9: 315-327, 2007.

HURT RD, EBBERT JO, HAYS JT, MCFADDEN DD: Treating tobacco dependence in a medical setting. Ca Cancer J Clin 59: 314-326, 2009.

KANNEL WB, WOLF PA, CASTELLI WP, D'AGOSTINO, RB: Fibrinogen and risk of cardiovascular disease. The Framingham Study. JAMA 258: 1183-1186, 1987.

KATO T, INOUE T, MOROOKA T, YOSHIMOTO N, NODE K: Short-term passive smoking causes endothelial dysfunction via oxidative stress in nonsmokers. Can J Physiol Pharmacol 84: 523-539, 2006.

KMETOVA A, KRALIKOVA E, STEPANKOVA L, ZVOLSKA K, BLAHA M, STICHA M, BORTLICEK Z, SCHROEDER DR, CROGHAN IT: Factors associated with weight changes in successful quitters participating in a smoking cessation program. Addict Behav 39: 239-245, 2014.

KRALIKOVA E, KMETOVA A, STEPANKOVA L, ZVOLSKA K, FELBROVA V, KULOVANA A, RAMES J, BORTLICEK Z, BLAHA M: Treatment of tobacco dependence in the Czech Republic. XIIIth Annual Meeting of the SRNT-Europe, September 8-11, 2011, Antalya, Turkey. Abstract Book, 175-175, 2011.

KRALIKOVA E, KMETOVA A, STEPANKOVA L, ZVOLSKA K, DAVIS R, WEST R: Fifty-two week continuous abstinence rates of smokers being treated with varenicline versus nicotine replacement therapy. Addiction 108: 1497-1502, 2013.

LEE AJ, FOWKES GR, LOWE GD, RUMLEY A: Determinants of fibrin D-dimer in the Edinburgh Artery Study. Arterioscler Thromb Vasc Biol 15: 1094-1097, 1995.

MILLS EJ, THORLUND K, EAPEN S, WU P, PROCHASKA JJ: Cardiovascular events associated with smoking cessation pharmacotherapies: a network meta-analysis. Circulation 129: 28-41, 2013.

PETERSON AL, HRYSHKO-MULLEN AS, CORTEZ Y: Assessment and diagnosis of nicotine dependence in mental health settings. Am J Addict 3: 192-197, 2003.

PURANIK R, CELERMAJER DS: Smoking and endothelial function. Prog Cardiovasc Dis 45: 443-458, 2003.

RAVEENDRAN M, WANG J, SENTHIL D, WANG J, UTAMA J, SHEN Y, DUDLEY D, ZHANG Y, WANG XL: Endogenous nitric oxide activation protects against cigarette smoking induced apoptosis in endothelial cells. FEBS Lett 579: 733-740, 2005.

SAMBOLA A, OSENDE J, HATHCOCK J, DEGEN M, NEMERSON Y, FUSTER V, CRANDALL J, BADIMON JJ: Role of risk factors in the modulation of tissue factor activity and blood thrombogenicity. Circulation 107: 973-977, 2003. 
SNAJDAR RM, BUSUTTIL SJ, AVERBOOK A, GRAHAM DJ: Inhibition of endothelial cell migration by cigarette smoke condensate. J Surg Res 96: 10-16, 2001.

SOVINOVÁ H, CSÉMY L: The Use of Alcohol and Tobacco in the Czech Republic 2012. National Institute of Public Health, 2013. Available at http://www.szu.cz/tema/podpora-zdravi/uzivani-tabaku-a-alkoholu-v-cr (assessed June 14, 2014).

STEPANKOVA L, KRALIKOVA E, ZVOLSKA K, KMETOVA A, BLAHA M, BORTLICEK Z, STICHA M, ANDERS M, SCHROEDER DR, CROGHAN IT: Tobacco treatment outcomes in patients with and without a history of depression, Czech Republic, 2005-2010. Prev Chronic Dis 10: E158, 2013.

THOMAS KH, MARTIN RM, DAVIES NM, METCALFE C, WINDMEIJER F, GUNNELL D: Smoking cessation treatment and risk of depression, suicide, and self harm in the Clinical Practice Research Datalink: prospective cohort study. BMJ 347: f5704, 2013, free full text at http:/www.ncbi.nlm.nih.gov/pmc/articles/PMC3805476/ (accessed June 14, 2014).

TÖRÖK J, GVOZDJÁKOVÁ A, KUCHARSKÁ J, BALAŽOVJECH I, KYSELÁ S, ŠIMKO F, GVOZDJÁK F: Passive smoking impairs endothelium-dependent relaxation of isolated rabbit arteries. Physiol Res 49: $135-141,2000$.

WANG Y, WANG L, AI X, ZHAO J, HAO X, LU Y, QIAO Z: Nicotine could augment adhesion molecule expression in human endothelial cells through macrophages secreting TNF-alpha, IL-1beta. Int Immunopharmacol 4: 1675-1686, 2004.

WHO: International Statistical Classification of Diseases and Related Health Problems 10th Revision http://apps.who.int/classifications/icd10/browse/2008/en (assessed June 14, 2014).

WILHELMSEN L: Coronary heart disease: epidemiology of smoking and intervention studies of smoking. Am Heart J 115: 242-249, 1988.

ZVOLSKA K, KRALIKOVA E, KMETOVA A, STEPANKOVA L, BLAHA M, STICHA M, BORTLICEK Z, CESKA R: The role of a center for tobacco-dependent in cardiovascular prevention. A retrospective study. Neuro Endocrinol Lett 33 (Suppl 2): 102-107, 2012.

ZVOLSKÝ M, NECHANSKÁ B, KRÁLÍKOVÁ E: The use of diagnoses related to tobacco use in the Czech Republic (in Czech). Cas Lek Cesk 151: 573-578, 2012. 